\title{
Literature Review of the Effects of Radiation and Temperature on the Aging of Concrete
}

D. L. Fillmore, Ph.D.

September 2004

Idaho National Engineering and Environmental Laboratory Bechtel BWXT Idaho, LLC 


\title{
Literature Review of the Effects of Radiation and Temperature on the Aging of Concrete
}

\begin{abstract}
D. L. Fillmore, Ph.D.
September 2004

Idaho National Engineering and Environmental Laboratory Idaho Falls, Idaho 83415
\end{abstract}




\begin{abstract}
The open literature and accessible United States Department of Energy-sponsored reports were reviewed for the effects of radiation and temperature on concrete. No effects of radiation were found for exposures less than $10^{10}$ neutron $/ \mathrm{cm}^{2}$ or $10^{10}$ Gy gamma for periods less than 50 years.

Reductions in compressive and tensile strength and a marked increase in volume are reported for exposures greater than $10^{20}$ neutron $/ \mathrm{cm}^{2}$ or $10^{10}$ rads of gamma. There are conflicting reports of damage for doses in the middle ranges.
\end{abstract}





\section{SUMMARY}

Concrete has been used in the construction of nuclear facilities because of two primary properties, its structural strength and its ability to shield radiation. Concrete structures have been known to last for hundreds of years, but they are also known to deteriorate in very short periods of time. The use of concrete in nuclear facilities for containment and shielding of radiation and radioactive materials has made its performance crucial for the safe operation of the facility. The accessible literature was searched for reports on the effects of radiation and temperature on concrete deterioration.

The effects of low doses, $<10^{10}$ neutron $/ \mathrm{cm}^{2}$ or $<10^{10}$ Gy gamma, of radiation over periods of less than 50 years do not seem to have a significant effect on the concrete. Longer-term exposure, over 100 years, has not been studied.

The effects of higher doses of radiation are not as clear, and some difference in reported results exists. For some concrete types, neutron exposures $>10^{10}$ neutron $/ \mathrm{cm}^{2}$, are reported to cause deterioration.

For high radiation exposure, $>10^{20}$ neutron $/ \mathrm{cm}^{2}$ or $>10^{10}$ rads of gamma, concrete has been reported to exhibit reduction in compressive and tensile strength and a marked increase in volume.

The effects of long-term exposure of concrete to elevated temperatures are a loss of water in the concrete leading to a decrease in compressive strength, changes in the modulus of elasticity, creep resistance, conductivity, and diffusivity. Generally speaking, the threshold of degradation is $95^{\circ} \mathrm{C}$, and the effects increase with increasing temperature and time exposure. 



\section{CONTENTS}

ABSTRACT iii

SUMMARY $\mathrm{V}$

ACRONYMS ix

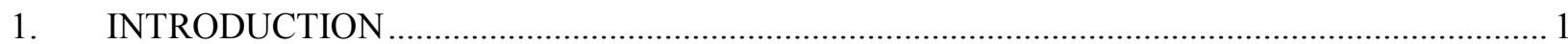

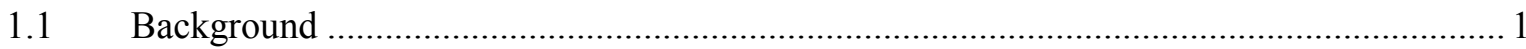

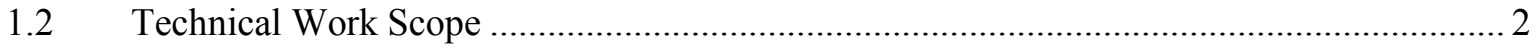

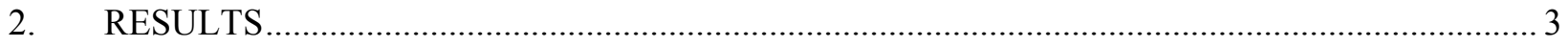

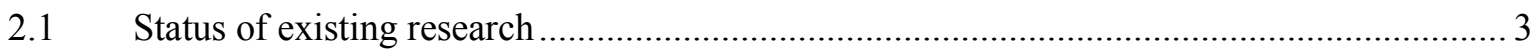

2.2 Physical Processes ........................................................................................... 3

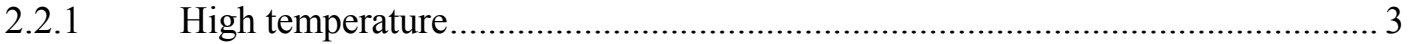

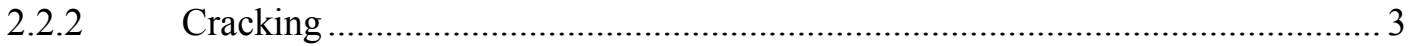

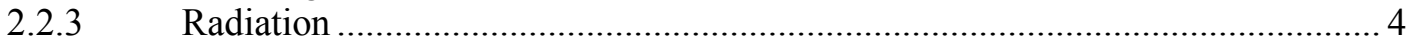

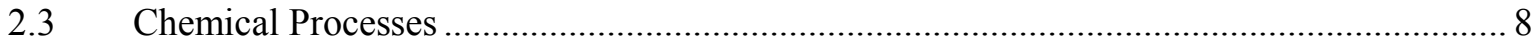

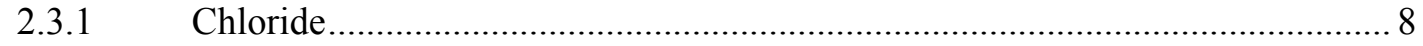

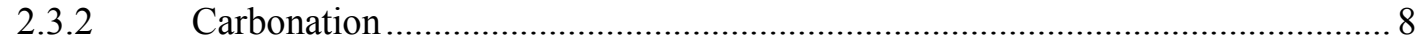

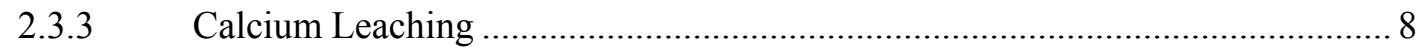

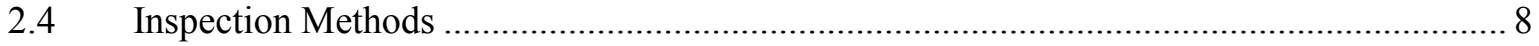

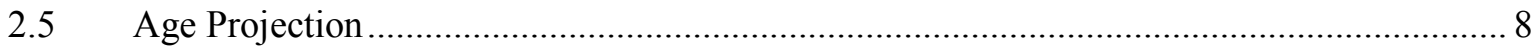

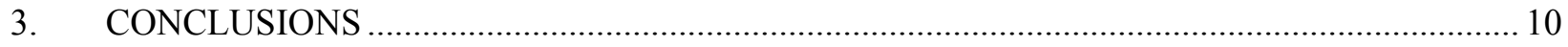

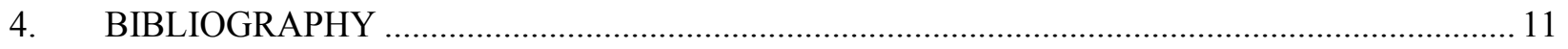

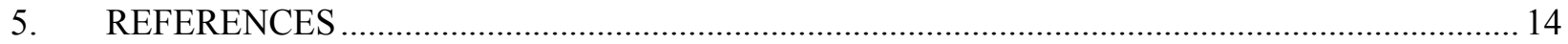

\section{FIGURES}

1. Compressive strength of concrete as a function of temperature .................................................. 4

2. Compressive strength of concrete exposed to neutron radiation $\mathrm{f}_{\mathrm{cu}}$ related to strength of

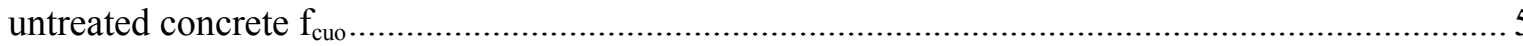

3. Tensile strength of concrete exposed to neutron radiation $f_{r u}$ related to strength of untreated concrete $\mathrm{f}_{\text {ruo }}$

4. Compressive and tensile strength of concrete exposed to gamma radiation $\mathrm{f}_{\mathrm{cu}}$ related to strength of untreated concrete $f_{\text {cuo }}$. 


\section{ACRONYMS}

ANS American Nuclear Society

ANSI American National Standard Institute

ASME American Society of Mechanical Engineers

CFR Code of Federal Regulations

DOE U.S. Department of Energy

GALL Generic Aging Lessons Learned

Gy Grey, a unit of radiation. Equal to $100 \mathrm{rad}$

INEEL Idaho National Engineering and Environmental Laboratory

Rad Radiation absorbed dose

SNF spent nuclear fuel

SSC Structures, systems, and components 


\section{Literature Review of the Effects of Radiation and Temperature on the Aging of Concrete}

\section{INTRODUCTION}

Available literature was reviewed for information pertinent to the effects of radiation and temperature on the deterioration of concrete. The accessible literature was searched for the following data on concrete deterioration.

- $\quad$ Concrete degradation

- $\quad$ Radiation effects on concrete

- $\quad$ Temperature effects on concrete

- $\quad$ Concrete aging.

The review covered the available open literature such as accessible U.S. Department of Energy (DOE) reports, available reports from user organizations (i.e., the American Concrete Institute), standards organizations (i.e., the American Society of Mechanical Engineers [ASME]), and professional organizations (i.e., the American Nuclear Society [ANS]). In addition, personal contacts were made with appropriate researchers at the Idaho National Engineering and Environmental Laboratory (INEEL) and other DOE sites.

\subsection{Background}

Concrete has been used in the construction of nuclear facilities because of two primary properties, its structural strength and its ability to shield radiation. Concrete structures have been known to last for hundreds of years, but they are also known to deteriorate in very short periods of time when exposed to deterious physical and chemical environmental conditions.

The use of concrete in nuclear facilities for containment and shielding of radiation and radioactive materials has made its performance crucial for the safe operation of the facility. Spent nuclear fuel (SNF) is stored in concrete structures, casks, and vaults for planned storage up to 40 years. This concrete is exposed to several conditions that have been shown to cause the concrete to deteriorate. These conditions include: freeze/thaw, heat, cracking, acids, chlorides, sulfates, carbonation, calcium leaching, and radiation. These conditions are compounded by the aging of these concrete structures.

The effect of radiation on concrete was studied between 1944 and 1956, and a literature review report was published. ${ }^{1}$ The data reported came from two types of tests, small exposed samples irradiated in high radiation fluxes and examinations of concrete cores removed from reactor shields, which had accumulated a significant amount of radiation (see Reference 1). Since that time, there have been additional studies published that have added data. No comprehensive studies have been published that incorporate all of the studies into one theory or conclusion. No studies could be located that addressed the performance of concrete in SNF storage facilities.

Several organizations have recognized the importance of understand the long-term performance of concrete and developing the ability to project lifetimes of concrete. These include the U.S. Nuclear 
Regulatory Commission, the International Atomic Energy Association, the American Concrete Institute, and the Electric Power Research Institute.

\subsection{Technical Work Scope}

The Central Research Institute of Electric Power Institute requested that the INEEL perform a literature search to identify papers and data related to temperature and radiation effects on concrete. Particular interest was to be paid to SNF storage. INEEL researchers prepared an annotated list of sources and this report. They provided a limited analysis of this information and identified key references on information and data that evaluates concrete performance for an extended period of time. 


\section{RESULTS}

\subsection{Status of Existing Research}

Long-term degradation of concrete structures under permanently humid environmental conditions is mainly influenced by interacting chemical and mechanical processes leading to the destruction of the microstructure by the dissolution of cement constituents and the propagation of micro-cracks. Mechanical damage accelerates the chemical degradation as a consequence of improving transport properties. ${ }^{2}$ Many of the concrete degradation processes have several potential causes, and it is difficult to separate which causes are responsible for observed damage. Early reported research results, for example, were unable to distinguish between damage caused by heat and damage cause by radiation (see Reference 1).

Since the year 2000, there have been many reports published about the deterioration of concrete. Some of these have reported the results of experimental work, and others have proposed models that might be used to predict the deterioration of concrete over periods of time. Many of the predictive models have focused on the micro-scale processes. Few of these have addressed the effects of radiation on the concrete. None of them have addressed the effects on radiation on concrete used for the dry storage of SNF.

The INEEL reviewed several hundred reports as a result of the search. Forty documents were determined to be pertinent to the request. In the sections below, various physical and chemical factors are identified, and the results of the research are presented. Included in this review are also references to concrete degradation from mechanisms other than radiation and heat that might be pertinent to the study of long-term dry storage of SNF in concrete structures.

\subsection{Physical Processes}

\subsubsection{High Temperature}

Tests on the effects of long-term exposure to elevated temperatures showed that the compressive strength in general tended to decrease with increasing temperature and with length of exposure. Temperature affects the modulus of elasticity. ${ }^{3}$ The moisture content in the concrete near a hot surface decreases because of pressure-induced flow. ${ }^{4}$ Heating of refractory concrete causes physical and chemical changes mainly because of removal of water. The compressive strength is reduced after exposure to about $540^{\circ} \mathrm{C} .{ }^{5}$ In conventional concrete, long-term exposure to high temperatures can cause changes in compressive strength, modulus of elasticity, creep resistance, conductivity, diffusivity, and shrinkage/expansion characteristics. Generally speaking, the threshold of degradation in the concrete is approximately $95^{\circ} \mathrm{C}$ (see Reference 5) In some of the investigations, radiation led to an increase in temperature of the concrete up to $250^{\circ} \mathrm{C}$. Such a temperature increase may cause considerable damage to the concrete even if there is no radiation effect (see Figure 1). ${ }^{6}$ The effect of temperature is even more pronounced on the tensile strength of concrete. A temperature increase from 20 to $100^{\circ} \mathrm{C}$ may cause a reduction of the tensile strength of concrete by as much as $50 \%$.

\subsubsection{Cracking}

The main distress of concrete components, which were identified where life extension of nuclear plants was being considered, were cracking. Cracking occurs virtually in all concrete

structures. ${ }^{7}$ Seventy-five percent of all reported degradation age effects were caused by cracking (see Reference 3). Several papers have reported the development of models that could be used to predict the performance, i.e., fracture, cracking, crack growth, temperature effects, and stress of concrete. ${ }^{8,9}$ Most of 


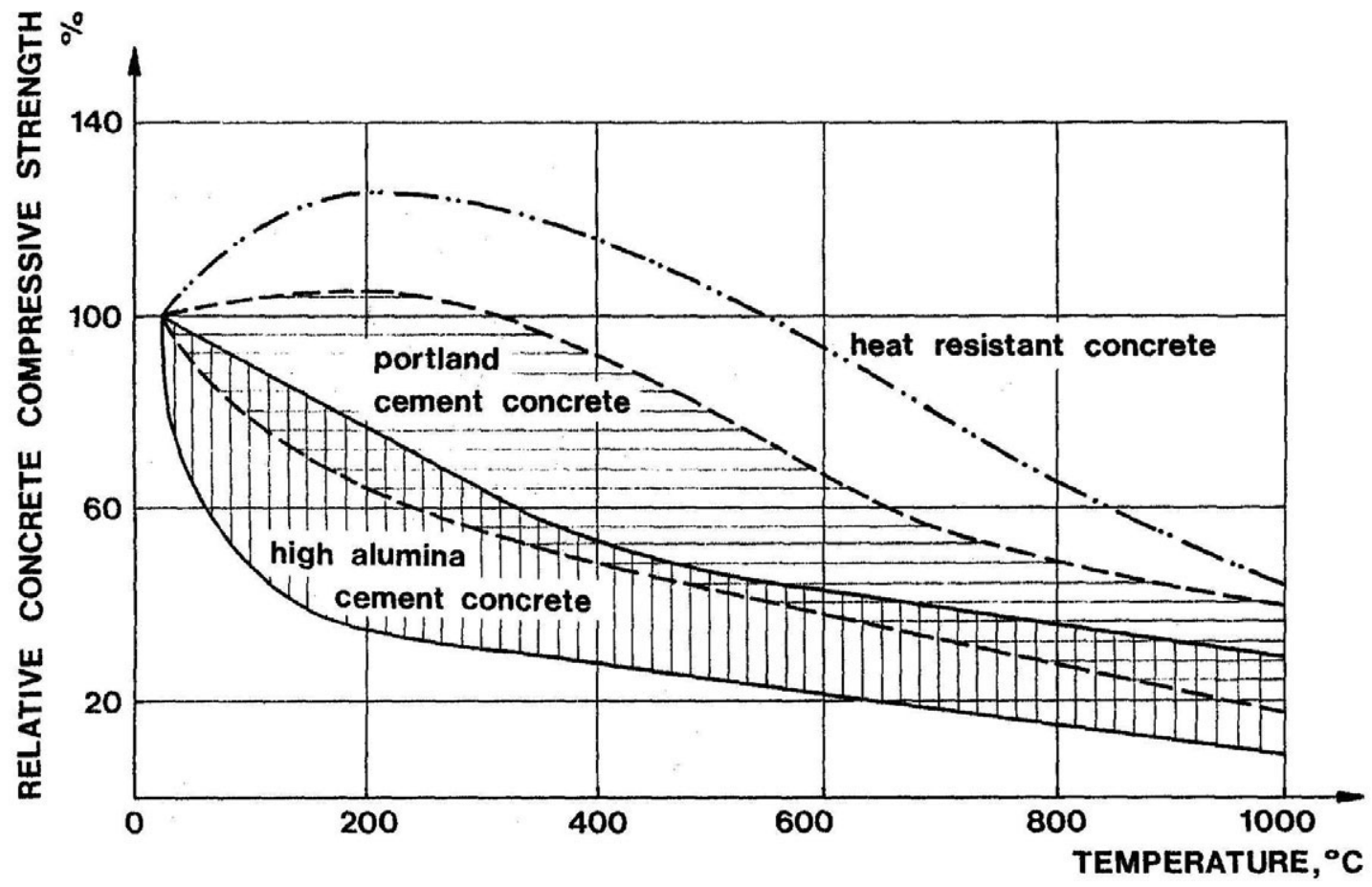

Figure 1. Compressive strength of concrete as a function of temperature (see Reference 6).

these papers also reported the values of the constants that were used in the models as functions of temperature and stress. In 2002, a 3-D lattice type fracture model for concrete was reported. ${ }^{10}$ This obtained more accurate representation than the results observed in actual physics experiments. The cracking of concrete can reduce its ability to shield radiation (see Reference 3). Cracks, irrespective of their origin, have a considerable influence on the moisture permeability of cementitous materials. As a consequence, the transport of aggressive substances is promoted, and the degradation process is further accelerated. ${ }^{11}$

\subsubsection{Radiation}

There are two possible causes of damage to concrete by irradiation. One is the change in the material properties caused by the radiation interactions with the material. Such damage might result from the breaking of bonds in the material or embrittlement of the material. The second possible cause might be the localized heating of the concrete caused by the absorption of the radiation energy. Radiation can also cause the dewatering of the concrete by the dissociation of the water. In many cases, it has not been possible to distinguish between the two mechanisms when concrete degradation has been identified.

Early historical data show that the compressive strength of concrete relative to a control sample decreases with radiation, see Figure 2 (see Reference 6). For conditions of radiation flux up to $2 \times 10^{19} \mathrm{nvt}$ (thermal) and temperatures to $120^{\circ} \mathrm{C}$, radiation damage to some concrete is apparently insignificant, while other types show considerable loss of strength. A similar effect is seen in tensile strength, see Figure 3 (see Reference 6). A similar effect is seen for pure gamma exposure up to 1,011 rad as shown in Figure 4 (see Reference 6). All effects on concrete due to radiation, per se, were too slight to reliably measure because of the gross effects from the increased temperature during exposure (see Reference 1). 


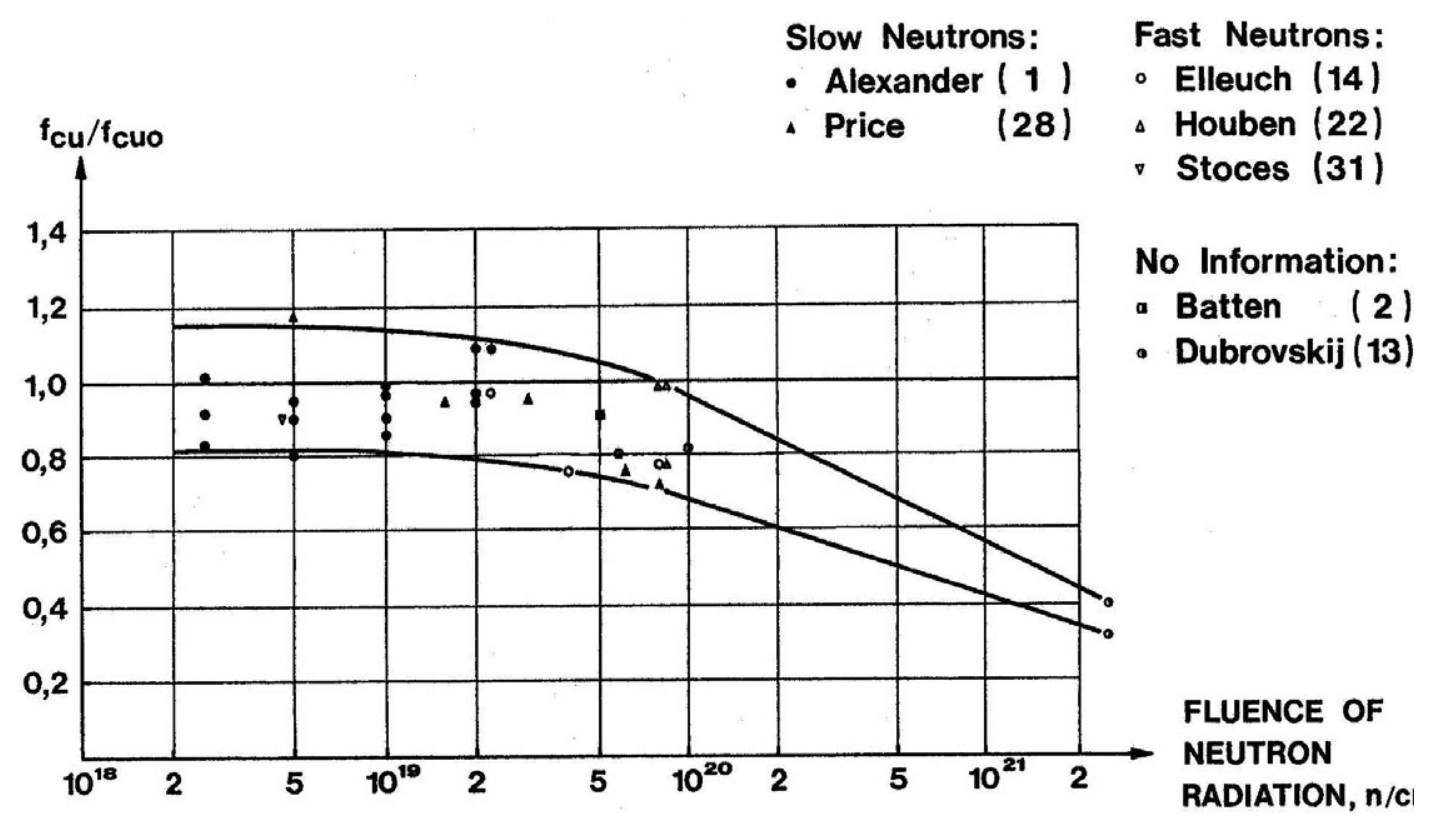

Figure 2. Compressive strength of concrete exposed to neutron radiation $\mathrm{f}_{\mathrm{cu}}$ related to strength of untreated concrete $f_{\text {cuo }}$ (see Reference 6 ).

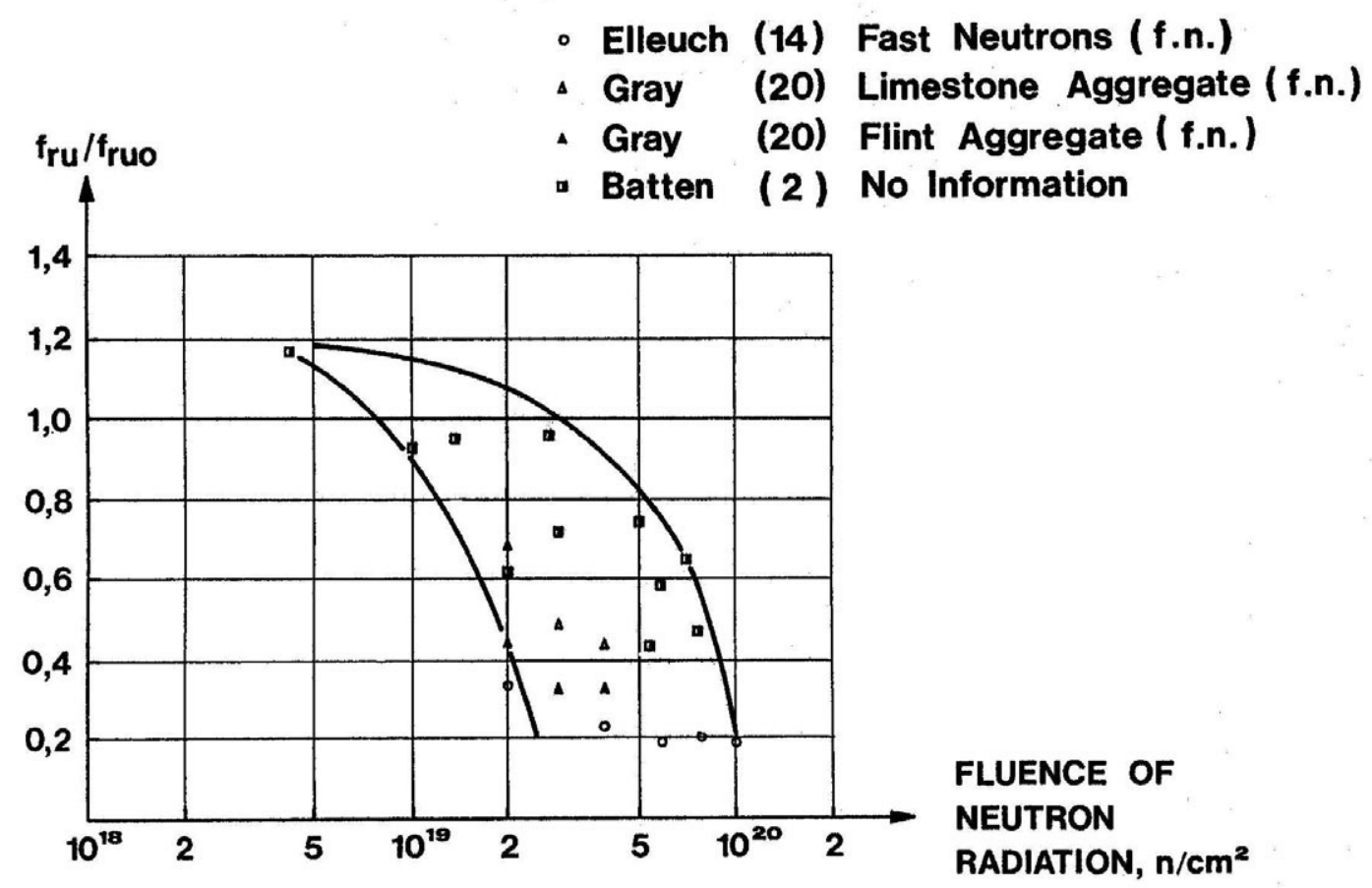

Figure 3. Tensile strength of concrete exposed to neutron radiation $f_{r u}$ related to strength of untreated concrete $f_{\text {ruo }}$ (see Reference 6). 


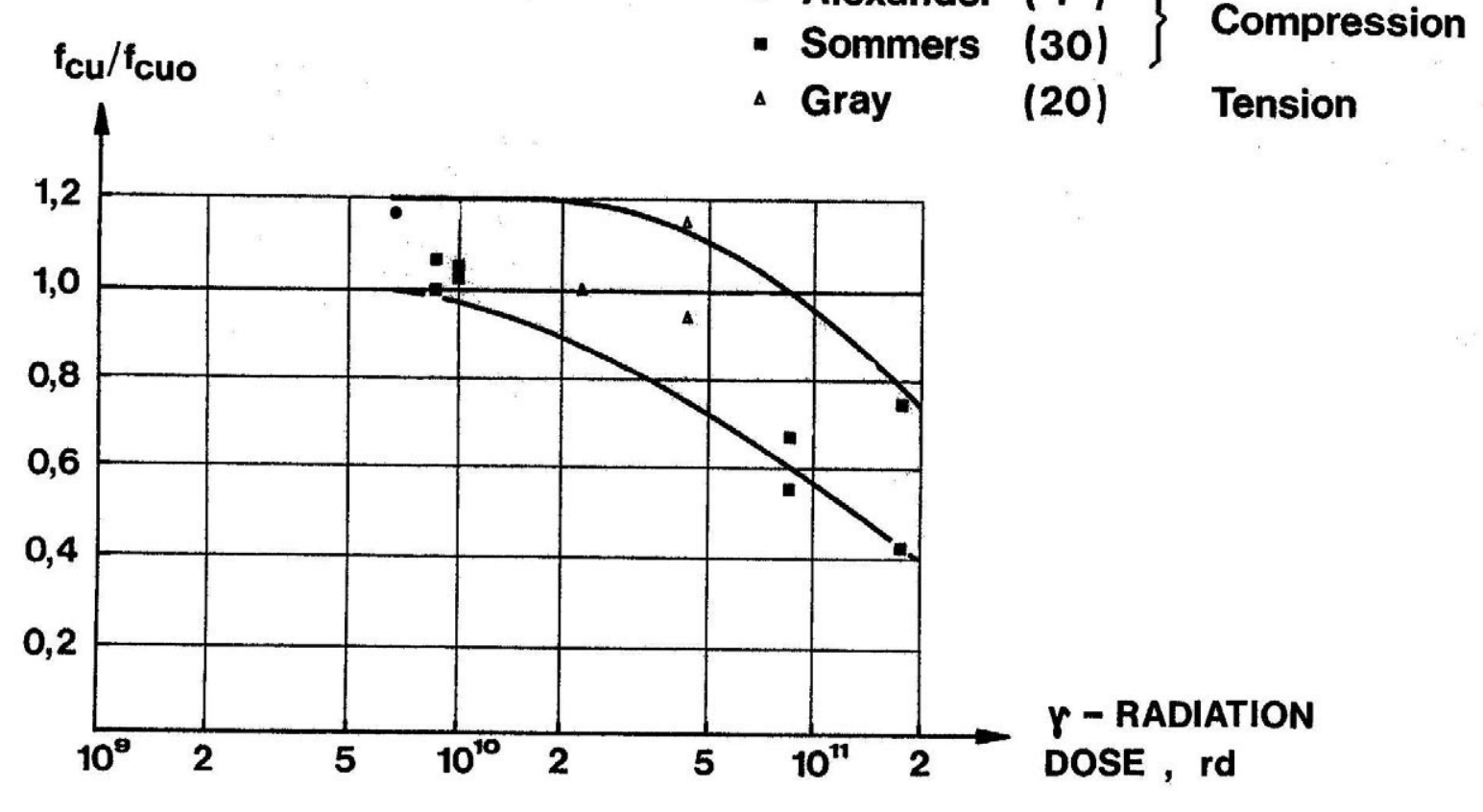

Figure 4. Compressive and tensile strength of concrete exposed to gamma radiation $f_{c u}$ related to strength of untreated concrete $f_{\text {cuo }}$ (see Reference 6).

Section III, Division 2 of the ASME Boiler and Pressure Vessel Code gives a radiation exposure level allowable to $1 \times 10^{20}$ neutrons $/ \mathrm{cm}^{2}$. These criteria are based on a limited number of data. Quantifying the extent to which irradiation will change the properties of concrete is impossible. This is because the quantification is dependent on many factors, such as variation of material properties, material state of testing, neutron energy spectrum, and neutron dose rate (see Reference 3). There is a great deal of variability in the reported data of the effects of radiation on concrete, and the results can be misleading (see Reference 3). Based on the existing reports some conclusions might be drawn (see References 3 and 6):

1. For some concretes, neutron radiation of $>10^{9}$ neutron $/ \mathrm{cm}^{2}$ may cause some reduction in compressive and tensile strength. The amount of damage depends on the properties of the concrete mixture.

1. The decrease of tensile strength due to neutron radiation is more pronounced than the decrease of compressive strength.

2. Resistance of concrete to neutron radiation apparently depends on the energy spectrum.

3. Resistance of concrete to neutron radiation depends on mix proportions, type of cement, and type of aggregate.

4. The effect of gamma radiation on concrete's mechanical properties requires clarification.

5. The deterioration of concrete properties associated with temperature rise resulting from irradiation is relatively minor. 
6. Coefficients of thermal expansion and conductivity of irradiated concrete differ little from those that would result from temperature-exposed concrete.

7. The modulus of elasticity of concrete when exposed to neutron irradiation decreases with increasing neutron fluence.

8. Creep of concrete is not affected by low-level radiation; but for high levels of exposure it is likely to increase.

9. For some concretes, neutron radiation with a fluence of $>10^{19}$ neutron $/ \mathrm{cm} 2$ can cause marked increase in volume.

10. In general, concrete's irradiation resistance increases as the irradiation resistance of aggregate increases.

11. Irradiation has little effect on shielding properties beyond the effect of moisture loss due to temperature increases.

There have been specific reports that both support and refute radiation damage to concrete. Examination of the concrete of the Materials Test Reactor fuel storage canal at the INEEL Test Reactor Area found that for gamma irradiation of $2^{11} \mathrm{R} / \mathrm{hr}$ in freely circulating water, there was a $50 \%$ loss of strength with significant surface damage. ${ }^{12}$ On the other hand, analysis of the shielding of the graphite reactor shield at Oak Ridge National Laboratory showed that the chemical properties and density of the shield had not changed appreciably between investigations done 8 years apart. However, the compressive strength at the reflector shield interface had dropped as much as $40 \%$. It was felt that damage from irradiation was less than that caused by relative temperature effects. ${ }^{13}$

According to the American National Standard Institute (ANSI) ANSI/ANS-6.4-1985, nuclear heating can be neglected if the incident energy fluxes are less than $10^{10} \mathrm{MeV} / \mathrm{cm} 2$-sec. Compressive strength and modulus of elasticity are degraded if the concrete is exposed to greater than $10^{19} \mathrm{n} / \mathrm{cm} 2$ or to an integrated dose of gamma radiation exceeding $10^{10}$ rads. $^{14}$

Concrete surrounding the pressure vessel of a nuclear reactor as a shielding material receives the highest radiation dose among concrete structures in a nuclear power plant. Assuming the lifetime of a commercial nuclear power plant to be 60 years, the integrated absorbed dose of the concrete is about $10^{9} \mathrm{~Gy}$ for gamma rays, which is lower than the critical dose. However, the integrated dose of fast neutrons for the concrete of a conventional pressurized water reactor is close to the critical one. Because the kinetic energy of fast neutrons is quickly dissipated while traveling in concrete, the thickness of concrete that is possible to exceed the critical dose is less than $20 \mathrm{~cm}$. The mechanical properties of the entire concrete structure may not be damaged by the radiation-induced degradation of such a thin layer. However, concrete pieces may be expected to fall from the surface. ${ }^{15}$

Because of the longevity requirements and importance of the concrete structures being considered, condition assessment and performance monitoring are considered to be of prime importance. Some guidance for general civil engineering structures is available through organizations such as the American Concrete Institute, the American Society of Civil Engineers, the Institute of Civil Engineers, and the International Union of Laboratories and Experts in Construction, Materials, Systems, and Structures. Unfortunately, little information is currently available that addresses condition assessment of concrete structures contained as part of a radioactive waste management facility. ${ }^{16}$ 


\subsection{Chemical Processes}

\subsubsection{Chloride}

Chlorides have been known to attack concrete for many years. The resistance of concrete to the penetration of chloride is one of the simplest measures to determine the durability of concrete. ${ }^{17}$ In marine environments, the reinforcing steel corrodes mainly because of the attack by chloride ions. ${ }^{18}$ Several reports have reported concrete mixtures that have resistance to chloride penetration.

\subsubsection{Carbonation}

Carbonation leads to a uniform corrosion of reinforcing steel that would accelerate crack formation and decrease structure life (see Reference 18). This is due to the reduction of the $\mathrm{pH}$, destroying the steel reinforcing members passive layer and accelerating steel corrosion that leads to concrete cracking (see Reference 18). Carbonation occurs generally faster in dry conditions because of water blocking the pores in the concrete in wet conditions. ${ }^{19,20}$ Carbonation of concrete has been shown to decrease water absorption, reduce chloride ion diffusion into concrete and slow down sulphate attack. ${ }^{21}$ The sorptivity of concrete decreases with the age of the concrete. This is believed to be caused by carbonation of the concrete (see Reference 21). Some numerical models have been developed to describe the process. ${ }^{22-24}$ High-performance concrete has been proposed. ${ }^{25,26}$

\subsubsection{Calcium Leaching}

Calcium leaching of cementitious materials has been identified as a severe long-term chemical degradation scenario of concrete structures. ${ }^{27}$ Calcium leaching kinetics in water is very slow. ${ }^{28}$ Aggressive environmental conditions such as ammonium nitrate can accelerate the process. Calcium leached in the pore fluid from the structural material is an equilibrium-based process (see Reference 28) and is diffusion limited (see Reference 2). The leaching is irreversible and reduces the stiffness and the limit load of structures, decreases brittleness, and changes the structural behavior (see Reference 2). It leads to a significant increase of the porosity of the material (see Reference 27).

\subsection{Inspection Methods}

Nuclear plant owners and operators are required to monitor the performance or conditions of structures, systems, and components (SSCs) against owner-established goals and to take appropriate corrective actions when the condition of a SSC does not conform to established goals. ${ }^{29}$ In order to verify the implementation of 10 CFR.65, the Nuclear Regulatory Commission issued inspection procedure 62002. Subsequently, on May 8, 1995, the Nuclear Regulatory Commission published a final rule amending 10 CFR Part 54 that contained the requirements an applicant must meet to renew an operating license. The Nuclear Regulatory Commission concluded that passive, long-lived components should be subject to an aging management review. Inspection and timely remedial actions will ensure continued safety of the structures (see Reference 29).

\subsection{Age Projection}

Several models have been developed in the last 5 years to address the mechanisms of the concrete deterioration and projection of lifetimes for the structures. ${ }^{2,30}$ The interactions between the structural materials and the environment must be considered and modeled (see Reference 23). The modeling of carbonation in concrete is a complex problem which requires, for realistic simulation, a systematic and 
robust finite element approach (see Reference 24). The presence of cracks has an important effect. One proposed model, CONDUR, is capable of handling geometry including cracks(see Reference 24).

The Structural Aging Program was initiated in 1988 and had the overall objectives of providing background data and information for identification and evaluation of the potential structural degradation processes as related to nuclear power plants. ${ }^{31}$ The NRC has studied the effects of aging on nuclear power plant and published Nuclear Power Plant Generic Aging Lessons Learned (GALL) Report ${ }^{32}$ where they document all of the known failures. 


\section{CONCLUSIONS}

Concrete has been used in the construction of nuclear facilities because of two primary properties, its structural strength and its ability to shield radiation. This use has made its long-term performance crucial for the safe operation of the facilities. Understanding the conditions that lead to concrete deterioration is therefore important. An open literature, and DOE document search found that research in this area has occurred since the late 1940s and has accelerated in the last 5 years.

Radiation can affect concrete in two mechanisms. One is the change in the material properties caused by the radiation interactions with the material. Such damage might be the breaking of bonds in the material or embrittlement of the material. The second possible cause might be the localized heating of the concrete caused by the absorption of the radiation energy. In many cases, it has not been possible to distinguish between the two mechanisms when concrete degradation has been identified.

The effects of low doses, $<10^{10}$ neutron $/ \mathrm{cm}^{2}$ or $10^{10} \mathrm{~Gy}$ gamma, of radiation over periods of less than 50 years do not seem to have a significant effect on the concrete. This is supported by existing research and standards published by ASME and ANSI. Longer-term exposure, over 100 years, has not been studied.

The effects of higher doses of radiation are not as clear, and some differences in reported results exist. For some concretes, neutron exposures $>10^{10}$ neutron $/ \mathrm{cm}^{2}$ may cause reduction in compressive and tensile strength and may depend on the neutron energy spectrum and the composition of the concrete.

For high radiation exposure, $10^{20}$ neutron $/ \mathrm{cm}^{2}$ or $10^{10}$ rads of gamma, concrete has been reported to exhibit reduction in compressive and tensile strength and a marked increase in volume, due to expansion of the aggregate and the shrinkage of cement paste. It was not possible to determine if these effects were caused by the heating and loss of water or by direct radiation effects. Either way, there are deterious effects reported.

The effects of long-term exposure of concrete to elevated temperatures are a loss of water in the concrete leading to a decrease in compressive strength, changes in the modulus of elasticity, creep resistance, conductivity, and diffusivity. Generally speaking, the threshold of degradation is $95^{\circ} \mathrm{C}$, and the effects increase with increasing temperature and time exposure. Rapid temperature increase or thermal cycling can lead to significant concrete degradation. 


\section{BIBLIOGRAPHY}

Bangert, F., S. Grasberger, D. Kuhl, G. Meschke, "Environmentally Induced Deterioration of Concrete: Physical Motivation and Numerical Modeling," Engineering Fracture Mechanics, Vol. 70, No. 7-8, May 2003.

Blosser, T., G. Bond, L. Lee, A Study of the Nuclear and Physical Properties of the ORNL Graphite Reactor Shield, Oak Ridge National Laboratory, ORNL-2195.

Braverman, J., Assessment of Age-Related Degradation of Structures and Passive Components for U.S. Nuclear Power Plants, NUREG/CR-6679, August 2000.

Castro P., E. Moreno, J. Genesca, "Influence of Marine micro-Climates on Carbonation of Reinforced Concrete Buildings," Cement and Concrete Research, Vol. 30, October 2000, pp. 1565-1571.

Clark, R., Radiation Damage to Concrete, Hanford Atomic Products Operation report, HW-56195, March 31, 1958.

Dias, W. P. S., "Reduction of Concrete Sorptivity with Age through Carbonation," Cement and Concrete Research, Vol. 30, 2000, pp. 1255-1261.

Dow, C., F. Glasser, "Calcium Carbonate Efflorescence on Portland Cement and Building Materials," Cement and Concrete Research, Vol. 33, 2003, pp. 147-154.

Edgemon, G., R. Anantatmula, Hanford Waste Tank System Degradation Mechanisms, WHC-SD-WMER-414, Rev. 0a, Hanford, June 26, 1995.

Gawin, D., F. Pesavento, "Modeling of Hydro-Thermal Behavior of Concrete at High Temperature with Thermo-Chemical and Mechanical Material Degradation," Computer Methods in Applied Mechanics and Engineering, Vol. 192, No. 13-14, March 2003.

Hanson, J., A. Ingraffea, "Using Numerical Simulations to Compare the Fracture Toughness Values for Concrete for the Size-Effect, Two Parameter and Fictitious Crack Models," Engineering Fracture Mechanics, Vol 70, No. 7-8, May 2003, pp. 1015-1027.

Hilsdorf, H., J. Kropp, H. Kock, The Effects of Nuclear Radiation on the Mechanical Properties Concrete, American Concrete Institute report SP-55-10, 1978.

Houst, Y., F. Wittmann, "Depth Profiles of Carbonates Formed during Natural Carbonation," Cement and Concrete Research, Vol. 32, 2002, pp. 1923-1930.

Hu, H., J. I. Liang, "Ultimate Analysis of BWR Mark III Reinforced Concrete Containment subjected to internal pressure," Nuclear Engineering and Design, Vol. 195, No. 1, January 2000, pp. 1-11.

Ichikawa, T., H. Koizumi, "Possibility of Radiation-Induced Degradation of Concrete by Alkali-Silica Reaction of Aggregates," Journal of Nuclear Science and Technology, Vol 39, No. 8, pp. 880-884.

Ichikawa, Y., G. England, "Prediction of Moisture Migration and Pore Pressure Build-Up in Concrete at High Temperatures," Nuclear Engineering and Design Vol. 228, No. 1-3, March 2004, pp. 245-259. 
Isgor, O., A. Razaqpur, "Finite Element Modeling of Coupled Heat Transfer, Moisture Transport and Carbonation Processes in Concrete Structures," Cement and Concrete Composites, Vol. 26, 2004, pp. 57-73.

Johannesson, B., P. Utgenannt, "Microstructural Changes Caused by Carbonation of Cement Mortar," Cement and Concrete Research, Vol. 31, 2001, pp. 925-931.

Jung, W., Y. Yoon, Y. Sohn, "Predicting the Remaining Service Life of Land Concrete by Steel Corrosion," Cement and Concrete Research, Vol. 33, 2003, pp. 663-677.

Kahn, M., C. Lynsdale, "Strength, Permeability, and Carbonation of High-Performance Concrete," Cement and Concrete Research, Vol. 32, 2002, pp. 123-131.

Kassir, M. K., K. K. Bandyopadhyay, M. Reich, Thermal Degradation of Concrete in the Temperature Range from Ambient to $315^{\circ} \mathrm{C}\left(600^{\circ} \mathrm{F}\right)$, BNL-52384, Brookhaven National Laboratory, June 1993.

Kasza, K., et al., Nuclear Power Plant Generic Aging Lessons Learned (GALL), NUREG/CR-6490, December 1996.

Kuhl, D., F. Bangert, G. Meschke, "Coupled Chemo-Mechanical Deterioration of Cementitious Materials. Part 1, Modeling," International Journal of Solids and Structures, Vol. 41, No. 1, January 2004, pp. 15-40.

Kuhl, D., F. Bangert, G. Meschke, "Coupled Chemo-Mechanical Deterioration of Cementitious Materials. Part 2, Numerical Methods and Simulations," International Journal of Solids and Structures, Vol. 41, No. 1, January 2004, pp. 41-67.

Lay, S., S. Liebl, H. Hibig, P. SchieB1, "New Method to Measure the Rapid Chloride Migration Coefficient of Chloride-Contaminated Concrete," Cement and Concrete Research, Vol. 34, 2004, pp. 421-427.

Lilliu, G., J. van Mier, “3D Lattice Type Fracture Code for Concrete,” Engineering Fracture Mechanics, Vol 70, No. 7-8, May 2003, pp. 927-941.

Markowitz, J., Concrete Handbook for Maxey Flats Waste Disposal, Appendix B, B324-D-001.

McCarthy, M., A. Giannakou, "In-situ Performance of CPF Concrete in a Coastal Environment," Cement and Concrete Research, Vol. 32, 2003, pp. 451-457.

Moreno, M., W. Marris, M. Alvarez, G. Duffo, "Corrosion of Reinforcing Steel in Simulated Concrete Pore Solutions Effect of Carbonation and Chloride Content," Corrosion Science, Vol. 46, 2004, pp. 2681-2699.

Naus, D., Concrete Component Aging and Its Significance Relative to Life Extension of Nuclear Power Plants, NUREG/CR-4652, September 1986.

Naus, D., Task Group Report on Aging of Concrete Structures Used to Construct Nuclear Power Plant Fuel-Cycle Facilities, Oak Ridge National Laboratory. 
Naus, D. J., A Review of the Effects of Elevated Temperature on Concrete Materials and Components with Particular Reference to the Modular High-Temperature Gas Cooled Reactor (MHTGR),

ORNL/NRC/LTR-88/2, Oak Ridge National Laboratory, March 1988.

Naus, D., B. Ellingwood, Managing Concrete Structure Aging-One Approach, Oak Ridge National Laboratory.

Naus, D., B. Ellingwood, H. Graves, "Methods for Assessing NNP Containment Pressure Boundary Integrity," Nuclear Engineering and Design, Vol. 228, No. 1-3, March, 2004, pp. 55-72.

Oh, B., S. Cha, B. Jang, S. Jang, "Development of High-Performance Concrete Having Resistance to Chloride Penetration," Nuclear Engineering and Design, Vol. 212, No. 1-3, March 2002, pp. 221-231.

Papadakis, V., "Effect of Supplementary Cementing Materials on Concrete Resistance Against Carbonation and Chloride Ingress," Cement and Concrete Research Vol. 30, 2000, pp. 291-299.

Pietruszczak, S., A. Winnicki, "Constructive Model for Concrete with Embedded Sets of Reinforcement," Journal of Engineering Mechanics, Vol. 129, No. 7, July 1, 2003.

Saetta, A., R. Vitaliani, "Experimental Investigation and Numerical Modeling of Carbonation Process in Reinforced Concrete Structures. Part 1 Theoretical Formulation," Cement and Concrete Research, Vol. 34, 2004, pp. 571-579.

Shah, V., Residual Life Assessment of Major Light Water Reactor Components - Volume 1, NUREG/CR4731, June 1987.

Sommers, J., "Gamma Radiation Damage of Structural Concrete Immersed in Water," Health Physics, Vol. 16, pp. 503-508.

Steffens, A., D. Dinkler, H. Ahrens, "Modeling Carbonation for Corrosion risk Prediction of Concrete Structures," Cement and Concrete Research, Vol. 32, 2002, pp. 935-941.

Thomas, M., J. Mathews, "Performance of PFA Concrete in a Marine Environment-10-year Results," Cement and Concrete Composites, Vol. 26, 2004, pp. 5-20.

Ulm, F., Monitoring the Durability Performance of Concrete in Nuclear Waste Containment Technical Progress Report No. 4, OSTI, Technical Progress Report No. 4 Project DE-FG03-99SF21891, June 30, 2000.

Ulm, F., E. Lemarchand, F Heukamp, "Elements of Chemo Mechanics of Calcium Leaching of CementBased Materials," Engineering Fracture Mechanics, Vol 70, No. 7-8, May 2003, pp. 871-889. 


\section{REFERENCES}

1. R. Clark, Radiation Damage to Concrete, Hanford Atomic Products Operation report, HW-56195, March 31, 1958.

2. D. Kuhl, F. Bangert, G. Meschke, "Coupled Chemo-Mechanical Deterioration of Cementitious Materials. Part 2, Numerical Methods and Simulations," International Journal of Solids and Structures, Vol. 41, No. 1, January 2004, pp. 41-67.

3. D. Naus, Concrete Component Aging and Its Significance Relative to Life Extension of Nuclear Power Plants, NUREG/CR-4652, September 1986.

4. Y. Ichikawa, G. England, "Prediction of Moisture Migration and Pore Pressure Build-Up in Concrete at High Temperatures," Nuclear Engineering and Design Vol. 228, No. 1-3, March 2004, pp. 245-259.

5. G. Edgemon, R. Anantatmula, Hanford Waste Tank System Degradation Mechanisms, WHC-SD-WM-ER-414, Rev. 0a, Hanford, June 26, 1995.

6. H Hilsdorf, J. Kropp, H. Kock, The Effects of Nuclear Radiation on the Mechanical Properties Concrete, American Concrete Institute report SP-55-10, 1978.

7. D. Naus, Concrete Component Aging and Its Significance Relative to Life Extension of Nuclear Power Plants, NUREG/CR-4652, September 1986.

8. H. Hu, J. I. Liang, "Ultimate Analysis of BWR Mark III Reinforced Concrete Containment subjected to internal pressure," Nuclear Engineering and Design, Vol. 195, No. 1, January 2000, pp. $1-11$.

9. J. Hanson, A. Ingraffea, "Using Numerical Simulations to Compare the Fracture Toughness Values for Concrete for the Size-Effect, Two Parameter and Fictitious Crack Models," Engineering Fracture Mechanics, Vol 70, No. 7-8, May 2003, pp. 1015-1027.

10. G. Lilliu, J. van Mier, “3D Lattice Type Fracture Code for Concrete,” Engineering Fracture Mechanics, Vol 70, No. 7-8, May 2003, pp. 927-941.

11. F. Bangert, S. Grasberger, D. Kuhl, G. Meschke, "Environmentally Induced Deterioration of Concrete: Physical Motivation and Numerical Modeling," Engineering Fracture Mechanics Vol. 70, No. 7-8, May 2003.

12. J. Sommers, "Gamma Radiation Damage of Structural Concrete Immersed in Water," Health Physics, Vol. 16, pp. 503-508.

13. T. Blosser, G. Bond, L. Lee, A Study of the Nuclear and Physical Properties of the ORNL Graphite Reactor Shield, Oak Ridge National Laboratory, ORNL-2195.

14. G. Edgemon, R. Anantatmula, Hanford Waste Tank System Degradation Mechanisms, WHC-SD-WM-ER-414, Rev. 0a, Hanford, June 26, 1995. 
15. T. Ichikawa, H. Koizumi, "Possibility of Radiation-Induced Degradation of Concrete by Alkali-Silica Reaction of Aggregates," Journal of Nuclear Science and Technology, Vol 39, No. 8, pp. 880-884.

16. D. Naus, Task Group Report on Aging of Concrete Structures Used to Construct Nuclear Power Plant Fuel-Cycle Facilities, Oak Ridge National Laboratory.

17. B. Oh, S. Cha, B. Jang, S. Jang, "Development of High-Performance Concrete Having Resistance to Chloride Penetration," Nuclear Engineering and Design, Vol. 212, No. 1-3, March 2002, pp. 221-231.

18. P. Castro, E. Moreno, J. Genesca, "Influence of Marine micro-Climates on Carbonation of Reinforced Concrete Buildings," Cement and Concrete Research, Vol. 30, October 2000, pp. 1565-1571.

19. Y Houst, F Wittmann, "Depth Profiles of Carbonates Formed during Natural Carbonation," Cement and Concrete Research, Vol. 32, 2002, pp. 1923-1930.

20. B. Johannesson, P. Utgenannt, "Microstructural Changes Caused by Carbonation of Cement Mortar," Cement and Concrete Research, Vol. 31, 2001, pp. 925-931.

21. W. P. S. Dias, "Reduction of Concrete Sorptivity with Age through Carbonation," Cement and Concrete Research, Vol. 30, 2000, pp. 1255-1261.

22. A. Steffens, D. Dinkler, H. Ahrens, "Modeling Carbonation for Corrosion risk Prediction of Concrete Structures," Cement and Concrete Research, Vol. 32, 2002, pp. 935-941.

23. A. Saetta, R. Vitaliani, "Experimental Investigation and Numerical Modeling of Carbonation Process in Reinforced Concrete Structures. Part 1 Theoretical Formulation," Cement and Concrete Research, Vol. 34, 2004, pp. 571-579.

24. O. Isgor, A. Razaquur, "Finite Element Modeling of Coupled Heat Transfer, Moisture Transport and Carbonation Processes in Concrete Structures," Cement and Concrete Composites, Vol. 26, 2004, pp. 57-73.

25. M. Kahn, C. Lynsdale, "Strength, Permeability, and Carbonation of High-Performance Concrete," Cement and Concrete Research, Vol. 32, 2002, pp. 123-131.

26. M. Thomas, J. Mathews, "Performance of PFA Concrete in a Marine Environment-10-year Results," Cement and Concrete Composites, Vol. 26, 2004, pp. 5-20.

27. F. Ulm, E. Lemarchand, F Heukamp, "Elements of Chemo Mechanics of Calcium Leaching of Cement-Based Materials," Engineering Fracture Mechanics, Vol 70, No. 7-8, May 2003, pp. 871-889.

28. D. Kuhl, F. Bangert, G. Meschke, "Coupled Chemo-Mechanical Deterioration of Cementitious Materials. Part 1, Modeling," International Journal of Solids and Structures, Vol. 41, No. 1, January 2004, pp. 15-40. 
29. D. Naus, B Ellingwood, H. Graves, "Methods for Assessing NNP Containment Pressure Boundary Integrity," Nuclear Engineering and Design, Vol. 228, No. 1-3, March 2004, pp. 55-72.

30. W. Jung, Y. Yoon, Y. Sohn, "Predicting the Remaining Service Life of Land Concrete by Steel Corrosion," Cement and Concrete Research, Vol. 33, 2003, pp. 663-677.

31. D. Naus, B. Ellingwood, Managing Concrete Structure Aging-One Approach, Oak Ridge National Laboratory.

32. K. Kasza et al., Nuclear Power Plant Generic Aging Lessons Learned (GALL), NUREG/CR-6490, December 1996. 